\title{
Pseudomonas simiae WCS417: star track of a model beneficial rhizobacterium
}

\author{
Corné M. J. Pieterse $($ B $•$ Roeland L. Berendsen • Ronnie de Jonge • Ioannis A. Stringlis • \\ Anja J. H. Van Dijken • Johan A. Van Pelt • Saskia C. M. Van Wees • Ke Yu • \\ Christos Zamioudis • Peter A. H. M. Bakker
}

Received: 4 August 2020 / Accepted: 26 November 2020 / Published online: 8 December 2020

(C) The Author(s) 2020

\begin{abstract}
Background Since the 1980s, numerous mutualistic Pseudomonas spp. strains have been used in studies on the biology of plant growth-promoting rhizobacteria (PGPR) and their interactions with host plants. In 1988, a strain from the Pseudomonas fluorescens group, WCS417, was isolated from lesions of wheat roots growing in a take-all disease-suppressive soil. In subsequent trials, WCS417 limited the build-up of take-all disease in field-grown wheat and significantly increased wheat yield. In 1991, WCS417 was featured in one of the first landmark studies on rhizobacteria-induced systemic resistance (ISR), in which it was shown to confer systemic immunity in carnation (Dianthus caryophyllus) against Fusarium wilt. The discovery that
\end{abstract}

Responsible Editor: Ismail Cakmak.

C. M. J. Pieterse $(\bowtie) \cdot R$. L. Berendsen $\cdot$ R. de Jonge $\cdot$

I. A. Stringlis - A. J. H. Van Dijken - J. A. Van Pelt •

S. C. M. Van Wees · P. A. H. M. Bakker

Plant-Microbe Interactions, Department of Biology, Science4Life,

Utrecht University, Padualaan 8, 3584 CH Utrecht, the

Netherlands

e-mail: c.m.j.pieterse@uu.nl

K. Yu

State Key Laboratory of Crop Stress Adaptation and Improvement, Henan University, Kaifeng 475004, China

C. Zamioudis

Plant Pathology, Department of Agricultural Development, Democritus University of Thrace, 193 Pantazidou, 68200 Orestiada, Greece
WCS417 conferred systemic immunity in the model plant species Arabidopsis thaliana in 1996 incited intensive research on the molecular mechanisms by which PGPR promote plant growth and induce broad-spectrum disease resistance in plants. Since then, the strain name appeared in over 750 studies on beneficial plantmicrobe interactions.

Scope In this review, we will highlight key discoveries in plant-microbe interactions research that have emerged from over 30 years of research featuring WCS417 as a model rhizobacterial strain. WCS417 was instrumental in improving our understanding of the microbial determinants that are involved in root colonization and the establishment of mutually beneficial interactions with the host plant. The model strain also provided novel insight into the molecular mechanisms of plant growth promotion and the onset and expression of rhizobacteria-ISR. More recently, WCS417 has been featured in studies on host immune evasion during root colonization, and chemical communication in the rhizosphere during root microbiome assembly.

Conclusions Numerous studies on the modes of action of WCS417 have provided major conceptual advances in our understanding of how free-living mutualists colonize the rhizosphere, modulate plant immunity, and promote plant growth. The concepts may prove useful in our understanding of the molecular mechanisms involved in other binary plant-beneficial microbe interactions, and in more complex microbial community contexts, such as the root microbiome. 
Keywords Biological control · Induced systemic resistance $\cdot$ Microbiome $\cdot$ Plant growth-promoting rhizobacteria $\cdot$ Plant immunity $\cdot$ Pseudomonas Rhizosphere

$\begin{array}{ll}\text { Abbreviations } \\ \text { BGC } & \text { Biosynthetic gene cluster } \\ \text { COG } & \text { Cluster of orthologous groups } \\ \text { ET } & \text { Ethylene } \\ \text { IAA } & \text { Indole-3-acetic acid } \\ \text { ISR } & \text { Induced systemic resistance } \\ \text { JA } & \text { Jasmonic acid } \\ \text { LPS } & \text { Lipopolysaccharide } \\ \text { MAMP } & \text { Microbe-associated molecular pattern } \\ \text { MTI } & \text { MAMP-triggered immunity } \\ \text { PGPR } & \text { Plant growth-promoting rhizobacteria } \\ \text { SA } & \text { Salicylic acid } \\ \text { SAR } & \text { Systemic acquired resistance } \\ \text { T3SS } & \text { Type III secretion system } \\ \text { TF } & \text { Transcription factor } \\ \text { VOCs } & \text { Volatile organic compounds } \\ \text { WCS } & \text { Willie Commelin Scholten }\end{array}$

\section{A star is born}

Pseudomonas fluorescens WCS417 was first mentioned in a study of Jan Lamers and co-workers (Lamers et al. 1988). The abbreviation "WCS" in the strain name refers to Willie Commelin Scholten, a biology student at the University of Amsterdam supervised by Prof. Hugo de Vries, who suddenly passed away in 1893. To commemorate their son, his fortunate parents financed a new institute: the Willie Commelin Scholten Phytopathological Laboratory at the universities of Utrecht and Amsterdam (Boonekamp et al. 2019; Schippers and Roosje 1997). All strain names collected by this institute received the label "WCS". WCS417 was isolated from lesions of wheat (Triticum sativum) roots growing in a soil in the Dutch Flevopolder that was suppressive to take-all disease caused by the soilborne fungus Gaeumannomyces graminis var. tritici. WCS417 stood out in a screen for the biological control of take-all disease in field-grown wheat, in which it significantly reduced disease incidence and increased wheat grain yield (Lamers et al. 1988). At the time of the isolation of WCS417 from wheat roots, decades of rhizosphere research had demonstrated that this thin zone of soil around the roots harbors both deleterious and beneficial microbes with the potential to affect plant growth and crop yields (Bakker et al. 2020; Schippers et al. 1987; Weller 1988). Ever since Hiltner (1904) argued that root exudates attract beneficial bacteria to the rhizosphere, where they affect plant quality and health, rhizosphere-associated microbes have been seen as an important source for the discovery of putative biocontrol agents (Hartmann et al. 2009). Beneficial members of the rhizosphere-inhabiting microbial community were considered to positively affect plant growth by enhancing the availability and uptake of mineral nutrients, the provision of plant-growth substances, and the suppression of deleterious microbes, including soil-borne pathogens. Hence, these beneficial nonsymbiotic microbes were coined plant growthpromoting rhizobacteria (PGPR) (Kloepper et al. 1980). Since its discovery in 1988 to the present-day golden age of root microbiome research, WCS417 has featured in numerous studies aiming to understand how free-living beneficial rhizobacteria engage in long-term relationships with their host plants, and how they provide life-supporting benefits to the plant. Here, we review the key discoveries of this model beneficial rhizobacterium in the field of plant-microbe interactions. Along the way, we highlight the biological concepts that WCS417 helped to unearth and shape, and led to our current understanding of the complexity of the interactions that evolved in the mutualistic relationship between plants and free-living beneficial microbes in the rhizosphere microbiome.

\section{Star wars: WCS417 is a versatile biocontrol agent}

WCS417 emerged from a large screen of potential biocontrol agents as being capable to suppress the soilborne fungus $G$. graminis var. tritici (Lamers et al. 1988). In this first study with WCS417, inoculation of wheat seeds with WCS417 prior to sowing reduced take-all disease severity in $G$. graminis var. tritici-inoculated fields from $27 \%$ to $6 \%$, while significantly improving wheat grain yield (Lamers et al. 1988). Also in other crops, WCS417 has been shown to suppress disease. For instance, in a greenhouse trial with banana (Musa sp.), WCS417 suppressed Panama disease incidence caused by Fusarium oxysporum f. sp. cubense by 87.4\% (Nel et al. 2006). In addition, in diverse crop and tree species, such as radish (Raphanus sativus), 
grapevine (Vitis vinifera), and eucalyptus (Eucalyptus urophylla), WCS417 effectively controlled plant diseases (Canchignia et al. 2017; Leeman et al. 1996a; Ran et al. 2005). The spectrum of effectiveness of the biological control activity seems to be relatively unspecific, as besides the soil-borne fungal diseases mentioned above, WCS417 was demonstrated to control other soil-borne diseases, such as bacterial wilt, caused by Ralstonia solanacearum (Ran et al. 2005) and the nematode Xiphinema index (Canchignia et al. 2017). In a recent study, colonization of the roots of peppermint (Mentha piperita) by WCS417 improved the antioxidant status of plants grown under drought stress leading to enhanced drought tolerance (Chiappero et al. 2019), and in the model plant Arabidopsis (Arabidopsis thaliana) it improved salt tolerance (Loo et al. 2020). Hence, WCS417 emerged as a versatile biocontrol agent with capacities that enable it to suppress various soilborne pathogens in a wide range of plant species, and to improve tolerance against abiotic stresses.

\section{Star quality of the WCS417 genome}

In 2015, the whole genome sequence of WCS417 was published (Berendsen et al. 2015). The 6.17 Mb genome of this plasmid-free strain is predicted to contain 5586 protein-coding genes (Fig. 1), which is comparable to the characteristics described for other Pseudomonas spp. strains (Loper et al. 2012). Phylogenetically, WCS417 falls in the P. fluorescens subgroup of fluorescent pseudomonads as defined by Mulet et al. (2010). The name "fluorescens" of this subgroup refers to the fact that fluorescent pseudomonads secrete the soluble fluorescent pigment pyoverdine (Fig. 2a), which functions as an iron-chelating siderophore. The WCS417 genome has a $100 \%$ nucleotide identity match with the type strain of $P$. simiae that was isolated from the lungs of a white-headed marmoset (Callithrix geoffroyi), a monkey endemic to forests in eastern Brazil (Vela et al. 2006). Accordingly, WCS417 was renamed from $P$. fluorescens WCS417 to P. simiae WCS417 in the publication on its genome sequence (Berendsen et al. 2015). Other P. fluorescens subgroup strains that according to their genome sequence identity belong to $P$. simiae are $P$. fluorescens subgroup strains PICF7 (Martínez-García et al. 2015) and R81 (Mathimaran et al. 2012). PICF7 was isolated from the roots of olive plants (Olea europaea) and was found to possess biological control activity against the soil-borne fungus Verticillium dahliae, causing a devastating disease in olive cultivation. Like WCS417, R81 stood out in a screen of 3000 bacteria for its elite plant growthpromoting properties (Roesti et al. 2006). Strain R81 was isolated from wheat roots grown in marginal soils in India, over $7500 \mathrm{~km}$ away from the location in the Netherlands where WCS417 emerged in a similar PGPR screen two decades earlier. Like WCS417, R81 also significantly increased wheat yield and grain quality in India, showcasing the plant beneficial potential that is encoded by the genomes of these globally represented Pseudomonas sp. genotypes.

Among the 11 secondary metabolite biosynthetic gene clusters (BGCs) found in the WCS417 genome (Fig. 1), most of them have the potential to synthesize metabolites that can either affect neighboring microbes or processes in the host plant that allow WCS417 to outcompete other microbes that aim to colonize the same niches in the rhizosphere (Berendsen et al. 2015; Stringlis et al. 2018c). These include BGCs for the production of the siderophore pyoverdine (Figs. 1 and 2a). Siderophores can chelate ferric iron in the soil environment, after which microbes can re-absorb the complex via TonB-dependent proteins that specifically recognize and transport specific siderophore-iron complexes into the periplasm. The WCS417 genome encodes 33 TonB-dependent proteins, suggesting that WCS417 is highly versatile in its ability to take up its own siderophore and those of other strains (Berendsen et al. 2015). Iron is an essential element for most organisms. However, its bioavailability is often limited because iron is mainly present as ferric iron, which is poorly soluble at neutral and high $\mathrm{pH}$. The capacity to produce and absorb ferric iron-chelating siderophores provides a competitive advantage in the rhizosphere that not only contributes to niche establishment, but also inhibits soil-borne fungal pathogens via direct competition for iron (Fig. 3; Verbon et al. 2017).

Many root-associated Pseudomonas sp. strains possess BGCs for the production of antimicrobial compounds, such as cyclic lipopeptide biosurfactants, 2,4diacetylphloroglucinol, phenazines, hydrogen cyanide, and pyrrolnitrin (Loper et al. 2012). However, none of these BGCs are present in the WCS417 genome. Only a few bacteriocins, bactericidal proteins with a narrow taxonomic range of effectiveness, and a betalactone with putative antibacterial activity were detected in the WCS417 genome (Fig. 1). Hence, WCS417 has a rather 


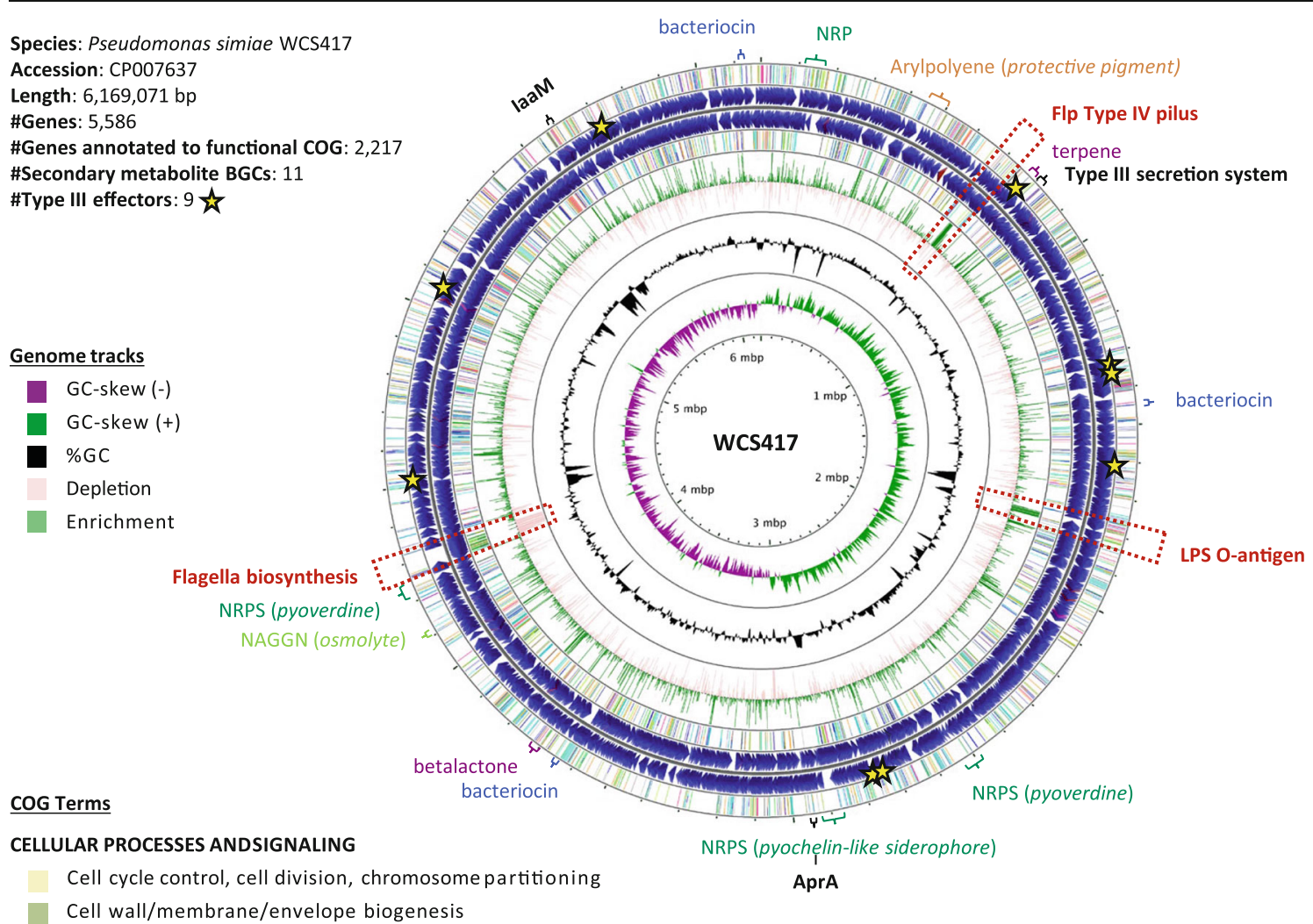

Cell wall/membrane/envelope biogenesis

Cell motility

Post-translational modification, protein turnover, and chaperones

Signal transduction mechanisms

Intracellular trafficking, secretion, and vesiculartransport

Defense mechanisms

Extracellular structures

Nuclear structure

Cytoskeleton

INFORMATION STORAGE ANDPROCESSING
RNA processing andmodification
Chromatin structure and dynamics
Translation, ribosomal structure and biogenesis
Transcription
Replication, recombination and repair

Fig. 1 Characteristics and features of the WCS417 genome. Rings from outside to inside: Ring 2 and 3, protein coding genes; Ring 1 and 4, genes annotated to functional clusters of orthologous groups (COGs). Key of COG terms is provided on the left; Ring 5 (green), enriched genes (Cole et al. (2017)); genes that when mutated lead to enhanced colonization on Arabidopsis roots (= negative effect on colonization by wild-type WCS417). E.g. LPS $\mathrm{O}$-antigen gene cluster and Flp type IV pilus gene cluster boxed in red; Ring 6 (light pink), depleted genes (Cole et al. (2017); genes

limited potential to produce known anti-microbial agents, which is in line with observations that in vitro antagonistic effects of WCS417 against fungal

\section{METABOLISM}

Energy production andconversion

Amino acid transport andmetabolism

Nucleotide transport andmetabolism

Carbohydrate transport and metabolism

Coenzyme transport and metabolism

Lipid transport andmetabolism

Inorganic ion transport andmetabolism

Secondary metabolites biosynthesis, transport, andcatabolism POORLY CHARACTERIZED

General function prediction only

Function unknown

that when mutated lead to reduced colonization on Arabidopsis roots (= required for maximal competitive colonization by wildtype WCS417). E.g. Flagella biosynthesis gene cluster boxed in red; Ring 7, \%GC; Ring 8 (purple/green), GC-skew (-/+); Ring 9, nucleotide position indicator. Secondary metabolite biosynthesis gene clusters (BGCs) are computed with antiSMASH (Blin et al. 2019). Type III effectors and AprA are from (Berendsen et al. 2015) and (Stringlis et al. 2019b). The circular diagram is prepared with CGView (Grant and Stothard 2008)

pathogens is largely determined via siderophoremediated competition for iron rather than antibiosis (Berendsen et al. 2015). 

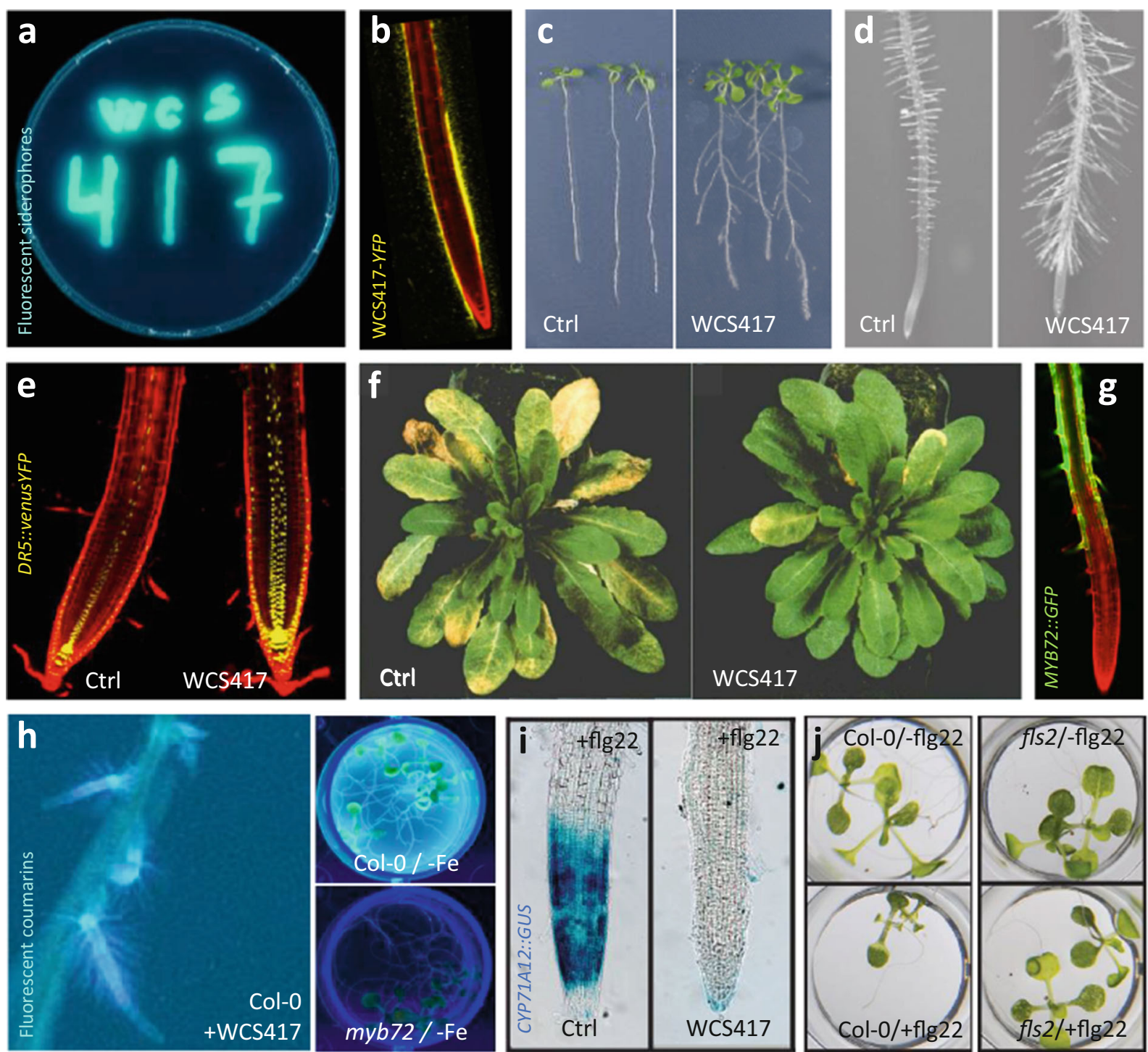

Fig. 2 Phenotypic characteristics of $P$. simiae WCS417 and its effects on Arabidopsis plants. a WCS417 producing a fluorescent pyoverdine siderophores on culture medium with low iron availability. b Confocal image of Arabidopsis primary root epiphytically colonized by Yellow Fluorescent Protein (YFP)-labelled WCS417. c WCS417 induces changes in root architecture and a 2-3 fold increase in shoot fresh weight. d WCS417-colonized roots develop longer root hairs. e WCS417 induces auxin response in roots as evidenced by a stronger activation of the auxinresponsive $p D R 5::$ venus YFP (nuclear) reporter. f First demonstration of WCS417-ISR in Arabidopsis against $F$. oxysporum f. sp. raphani. g WCS417 induces the expression of the root-specific transcription factor MYB72, which is essential for the onset of ISR. Shown is a confocal image of an Arabidopsis $p M Y B 72: \because G F P$

Genomes of Pseudomonas spp. typically contain gene clusters for five of the six identified bacterial protein secretion systems (type I, II, III, V and VI). It reporter line. h WCS417 and Fe deficiency induce secretion of fluorescent coumarins, which are produced in a MYB72dependent manner. i Flg22-induced growth-defense tradeoffs (flg22 treatment suppresses growth of wild-type Arabidopsis Col-0 seedlings, but not in flagellin receptor mutant fls 2 ). $\mathbf{j}$ WCS417 suppresses flg22-induced root immune response, as evidenced by suppression of flg22-responsive $p C Y P 71 A 12:: G U S$ gene expression by live WCS417 bacteria. B, adapted from Pieterse et al. (2014); C, adapted from Wintermans et al. (2016), D and E, adapted from Zamioudis et al. (2013), F, adapted from Pieterse et al. (1996); G, adapted from Zamioudis et al. (2015); H, adapted from Stringlis et al. (2018b); I and J, adapted from Stringlis et al. (2018a) and Yu et al. (2019a)

allows them to secrete proteins to adapt to different environments, compete with other microbes, or establish a pathogenic or mutualistic interaction with a host. 


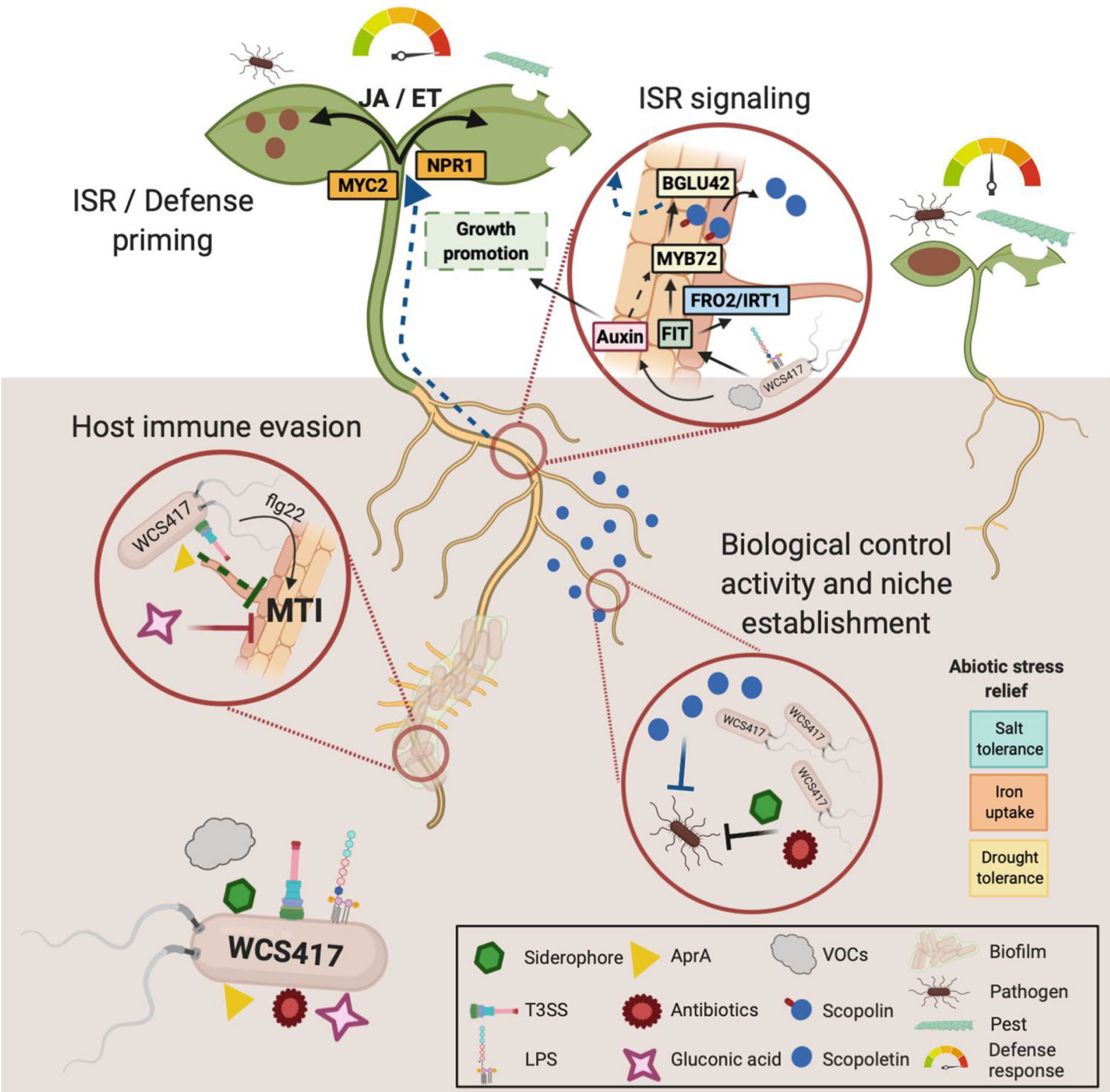

Fig. 3 Schematic representation of processes and molecular components of the interaction between WCS417 and plant roots. On the left a plant of which the roots are colonized by WCS417, on the right an untreated plant. WCS417 produces many compounds (symbols explained in the box) by which it influences interactions with other microbes and the host plant. These processes include biological control of soil-borne pathogens, niche establishment in the rhizosphere, host immune evasion to facilitate root colonization, elicitation of induced systemic resistance (ISR), plant growth

WCS417 contains one or more copies of each of these protein secretion systems (Berendsen et al. 2015; Stringlis et al. 2019b). Interestingly, the WCS417 genome also contains genes known to be required for the promotion, and abiotic stress relief. Details of the components mentioned in the figure are explained in the main text. Dashed blocked lines (--|) and arrows indicate predicted activities, solid blocked lines and arrows indicate proven activities. ET, ethylene; flg22, 22-amino acid immunogenic epitope of flagellin; ISR, induced systemic resistance; JA, jasmonic acid; LPS, lipopolysaccharide; MTI, MAMP-triggered immunity; T3SS, type III secretion system; VOCs, volatile organic compounds. The figure was designed using Biorender (https://biorender.com)

Flp Type IV pilus assembly, a trait involved in root colonization (Lugtenberg et al. 2001). The T3SS is of particular interest in host-microbe interactions. During co-evolution with their animal or plant host, 
Pseudomonas spp. have developed the T3SS to deliver immune-suppressive effector molecules to the host cell, therewith facilitating effective colonization (Alfano and Collmer 2004). The T3SS is composed of approximately 25 proteins that form a nanomachine with needleshaped extension through which effector proteins can be injected into host cells. Although the T3SS and its cognate effector proteins are typical features of pathogenic bacteria, there are also examples of mutualistic rhizobia and free-living PGPR that possess a functional T3SS (Zamioudis and Pieterse 2012). Bioinformatic analysis of the WCS417 T3SS showed that it is evolutionary different from those of phytopathogenic Pseudomonas spp. (Stringlis et al. 2019b). WCS417 genome mining predicted 9 putative T3SS-secreted effectors (Fig. 1; Berendsen et al. 2015; Stringlis et al. 2019b), including a homologue of the previously characterized T3SS-secreted effector RopE of $P$. fluorescens SBW25 (Preston et al. 2001). However, the role of the putative T3SS-secreted WCS417 effectors in suppression of host immunity, remains to be investigated.

Like pathogens, beneficial root-associated microbes possess microbe-associated molecular patterns (MAMPs) that can be recognized by cognate immune receptors in the host cell. MAMP recognition activates a MAMP-triggered immune (MTI) response in the host that serves as a first line of defense that keeps nonadapted microbes in check that attempt to invade the host. Hence, to establish a mutually beneficial relationship with its host, mutualistic microbes need to suppress or evade local host immune responses. The WCS417 genome contains gene clusters for the biosynthesis of MAMPs, such as flagellin and lipopolysaccharides (LPSs) (Fig. 1; Berendsen et al. 2015). And indeed purified flagellin and LPS of WCS417 were shown to elicit MTI in tobacco (Nicotiana tabacum) suspension cells (Van Loon et al. 2008). However, colonization of Arabidopsis roots by WCS417 actively suppresses the MTI response triggered by the immunogenic flagellin epitope flg22 (Millet et al. 2010), suggesting that WCS417 has an active immune suppressive mechanism in place that prevents Arabidopsis roots from activating costly defenses when colonizing the roots. For further details on WCS417-mediated root immune evasion, see paragraph "Among the stars: WCS417 in a root microbiome context".

Auxins have established roles in both plant growth and immunity (Kazan and Manners 2009). Microbially produced auxins can affect plant development and root architecture and suppress plant defenses (Spaepen and Vanderleyden 2011). In both plants and microbes, the main precursor of the functional auxin indole-3-acetic acid (IAA) is tryptophan. In bacteria, a number of different IAA biosynthesis pathways have been elucidated (Spaepen and Vanderleyden 2011). Although the biosynthesis pathways in plants and microbes show some degree of similarity, it is not clear how the plant and microbial IAA biosynthesis pathways are related (Yue et al. 2014). In Arabidopsis, WCS417 influences root development and promotes plant growth in an auxin-dependent manner (Zamioudis et al. 2013). However, the WCS417 genome does not seem to contain a functional IAA biosynthesis gene cluster, as only a homologue of IaaM could be detected and the other components of the auxin biosynthesis pathway seem to be lacking (Fig. 1). Nevertheless, Schwachtje et al. (2012) showed that WCS417 can produce IAA when fed with the precursor tryptophan, suggesting that WCS417 may synthesize IAA via an alternative route.

Knowing which genes are present in WCS417 automatically provides insight into which genes are absent. This provides new avenues for comparative genomic analysis of phenotyped bacterial Pseudomonas spp. strains to identify functionally validated bacterial genes associated with specific functions (Stringlis et al. 2018c). Such an approach was followed by Beskrovnaya et al. (2020) who were interested in identifying Pseudomonas genes that are associated with the induced systemic susceptibility (ISS) to infection by the bacterial leaf pathogen Pseudomonas syringae pv. tomato that they observed in Arabidopsis plants upon colonization of the roots by selected Pseudomonas spp. strains. They compared the genomes of the ISS-eliciting Pseudomonas spp. strains, with the genomes of Pseudomonas spp. strains (including WCS417) that trigger induced systemic resistance (ISR) against this pathogen. By comparing the genomes of Pseudomonas spp. with opposite effects on plant immunity, the authors identified a gene locus that is responsible for ISS. Unfortunately, the functions of the genes in this locus remained elusive in this study. With more and more Pseudomonas spp. genomes becoming available, combined with extensive bacterial phenotyping, such an approach will accelerate future functional genomics of the biology of beneficial rhizobacteria. 


\section{WCS417 root colonization: Start of a mutually beneficial relationship}

Colonization of the rhizosphere is a crucial step for all root-associated microbiota. Pseudomonas spp. are among the best root colonizers and are therefore typically highly enriched in the rhizosphere (Bakker et al. 2013). Using fluorescent labelled WCS417, it was shown in the grass species Brachypodium distachyon (Gao et al. 2018) and in Arabidopsis (Pieterse et al. 2014) that WCS417 colonizes the root exterior, but does not grow endophytically in the root tissue (Fig. 2b). However, in tomato (Solanum lycopersicum) WCS417 was shown to also be able to colonize the roots endophytically (Duijff et al. 1997). WCS417 outcompetes related $P$. fluorescens subgroup strains, such as $P$. fluorescens SS101 (Pangesti et al. 2017), in the Arabidopsis rhizosphere, demonstrating its rhizosphere competence. Various environmental factors have been shown to impact WCS417 colonization, such as soil nutritional status and atmospheric $\mathrm{CO}_{2}$ levels (Williams et al. 2018). In an elegant study, Cole et al. (2017) performed transposon mutagenesis sequencing in WCS417 to identify bacterial genes that impact colonization of the Arabidopsis root system. They applied a saturated transposon mutant library of WCS417 on the root system of axenic Arabidopsis plants and assessed the enrichment and depletion of mutant genotypes in the established mutant library community. A total of 115 WCS417 genes (2\% of all WCS417 genes) were demonstrated to be required for maximal competitive colonization of the Arabidopsis root system. Among the genes with a positive effect on colonization were genes with roles in bacterial motility, such as all genes in the flagellum biosynthesis gene cluster (Fig. 1), but also genes related to carbon metabolism (Cole et al. 2017). Other genes had a negative effect on root colonization, including genes from the lipopolysaccharide (LPS) biosynthesis cluster (Fig. 1). This suggests that mutation of the LPS biosynthesis genes provides WCS417 with a competitive benefit in the Arabidopsis rhizosphere, a feature that could be utilized in microbial breeding for enhanced rhizosphere competence. Studies on WCS417 root colonization have almost exclusively been performed in the absence of biotic or abiotic stresses. However, recent advances in plant microbiome research revealed that in response to pathogen attack, plant roots can recruit specific beneficial microbes or microbial functions to their roots that in turn provide protection against the invading pathogen (Bakker et al. 2018;
Berendsen et al. 2018; Carrion et al. 2019; Yuan et al. 2018). Future studies should reveal whether and how WCS417 colonization and activity are affected in response to chemical cues that are secreted in the rhizosphere under biotic or abiotic stress conditions.

\section{Plant growth promotion}

PGPR are named after their capacity to promote plant growth (Kloepper et al. 1980). Mechanisms of plant growth promotion by PGPR have been studied in detail (Lugtenberg and Kamilova 2009; Verbon and Liberman 2016). WCS417 promotes plant growth via different mechanisms; one way is via its biological control capacity that can directly inhibit soil-borne pathogens and, thus, reduce disease incidence in the host plant. For instance, studies with WCS417 mutants lacking the iron-chelating siderophore pyoverdine, demonstrated that wild-type WCS417 was capable of promoting plant growth by suppressing Fusarium wilt pathogens in carnation (Dianthus caryophyllus) via competition for iron in the soil environment (Duijff et al. 1993; Van Peer et al. 1990). Also in pathogen-free systems, WCS417 was capable of promoting plant growth. In WCS417amended sterilized soil, growth of Arabidopsis produced $32 \%$ more fresh weight than in non-amended sterile soil (Pieterse and Van Loon 1999). When grown in vitro on synthetic growth medium, application of WCS417 to the root system of Arabidopsis seedlings visualized the morphological effects that this PGPR can have on root architecture and plant growth. Upon colonization of the roots by WCS417, Arabidopsis plants produced significantly more lateral roots (Fig. 2c) and the root hairs were extended (Fig. 2d; Poitout et al. 2017; Regaiolo et al. 2020; Zamioudis et al. 2013). These WCS417-induced features provided the plant with an enhanced capacity to take up water and mineral nutrients, resulting in a 2-3 fold increase in shoot fresh weight in this experimental setup (Wintermans et al. 2016; Zamioudis et al. 2013). Recently, WCS417 was shown to alter the expression of 13 genes of the SWEET and ERD6-like sugar transporter gene families in Arabidopsis seedlings. Of these, SWEET11 and SWEET12 were demonstrated to be functionally involved in WCS417-mediated plant growth-promoting effects (Desrut et al. 2020). Zamioudis et al. (2013) showed that this growth response was mediated by enhanced signaling of the plant growth hormone auxin, 
as WCS417-treated roots showed enhanced activity of the auxin reporter DR5::venusYFP (Fig. 2e) and the root architectural changes induced by WCS417 were blocked in the Arabidopsis auxin response triple mutant tirl afb2 afb3. Interestingly, the blend of volatile organic compounds (VOCs) produced by WCS417 induced similar root architectural changes and enhanced the shoot fresh weight of Arabidopsis (Blom et al. 2011; Zamioudis et al. 2013), suggesting that stimulation of endogenous auxin responses by WCS417 VOCs plays a role in plant growth promotion (Fig. 3). To date, several microbial volatiles have been identified that have effects on plant growth, including ones that interfere with plant auxin signaling (Fincheira and Quiroz 2018). However, the nature of the WCS417 VOCs involved in plant growth promotion is currently unknown.

The capacity of plants to benefit from the growthpromoting activity of WCS417 was shown to be dependent on plant genotype. In a genome-wide association study with 302 Arabidopsis accessions, it was shown that Arabidopsis displayed extensive genetic variation in the capacity to respond to WCS417 VOCs, with reference accession Col-0 (Fig. 2c) being only an average responder. Subsequent genome-wide association mapping of the observed WCS417-induced changes in root and shoot growth characteristics surfaced 10 genetic loci that are highly associated with the responsiveness of Arabidopsis to the WCS417 growth-promoting activity (Wintermans et al. 2016). Among the identified candidate genes for WCS417-mediated growth promotion were genes involved in important plant growth processes, including photosynthesis and cytokinin transport. This supports the notion that plant genotype-mediated effects on plantbeneficial microbe interactions can have a profound effect on plant performance (Haney et al. 2015) and might be useful in future breeding strategies for beneficial microbe-optimized crops (Pieterse et al. 2016).

\section{Induced systemic resistance (ISR): Starring WCS417}

In 1991, it was demonstrated for the first time that PGPR not only directly control soil-borne pathogens, but can also improve plant health through stimulation of the plant immune system, a phenomenon called PGPR-ISR (Alström 1991; Van Peer et al. 1991; Wei et al. 1991). In the seminal paper of Van Peer et al. (1991), colonization of the roots of carnation plants by WCS417 was shown to elicit ISR in distal plant tissues, resulting in an enhanced level of protection against infection by the Fusarium wilt pathogen $F$. oxysporum f. sp. dianthi. This enhanced resistance was associated with an increased production of antimicrobial phytoalexins at the site of pathogen infection. The authors concluded that signals emerging during the WCS417-root interaction sensitize distal plant tissues for enhanced pathogen defense, a phenomenon that later would be termed "defense priming" (Conrath et al. 2006; Martinez-Medina et al. 2016). After this first demonstration in carnation, WCS417-ISR was demonstrated in many other plant species, including radish (Leeman et al. 1995a), Arabidopsis (Pieterse et al. 1996), tomato (Duijff et al. 1998; Meziane et al. 2005), bean (Bigirimana and Höfte 2002; Meziane et al. 2005), banana (Nel et al. 2006), and grapevine (Verhagen et al. 2010). The induced resistance triggered by WCS417 on the roots was effective against a broad range of plant pathogens in aboveground tissues, which is typical for PGPR-ISR (Pieterse et al. 2014). Even a number of insect pests were shown to be controlled by WCS417-ISR, including those caused by Spodoptera exigua (Van Oosten et al. 2008), Mamestra brassicae (Pangesti et al. 2016, 2017), and Trichoplusia ni (Haney et al. 2018), although WCS417 induced an enhanced susceptibility to some others, such as the aphid Myzus persicae (Pineda et al. 2010, 2012). In the quest for bacterial determinants responsible for the onset of ISR in plant roots, several microbial determinants of WCS417 have been shown to contribute. Flagellin, LPS and siderophores of WCS417 elicit molecular immune responses in tobacco suspension culture cells, indicating that these molecules have the potential to activate the plant immune system (Van Loon et al. 2008). The O-antigenic side chain of WCS417 LPS was shown to be required for the elicitation of ISR in radish, carnation, and Arabidopsis (Leeman et al. 1995a; Van Peer and Schippers 1992; Van Wees et al. 1997). However, purified siderophores of WCS417 did not trigger ISR in radish (Leeman et al. 1996b), suggesting that different hosts perceive different ISR elicitors.

In the early $1990 \mathrm{~s}$, when beneficial rhizobacteria were demonstrated to trigger ISR, research on a phenotypically similar form of systemically induced resistance was booming. In the $1960 \mathrm{~s}$, the term systemic acquired resistance (SAR) was coined for the phenomenon in which uninfected plant tissues develop an enhanced level of disease resistance in response to a localized infection elsewhere in the plant (Ross 1961). Like 
PGPR-ISR, pathogen-induced SAR was shown to be effective against a broad spectrum of plant diseases and associated with the abundant accumulation of antimicrobial pathogenesis-related (PR) proteins (Van Loon et al. 2006; Van Loon and Van Kammen 1970). Physiological and genetic studies in tobacco plants showed that the plant hormone salicylic acid (SA) is an important regulator of SAR (Durrant and Dong 2004; Gaffney et al. 1993; Vlot et al. 2009). Surprisingly, WCS417ISR in radish seemed not to be associated with the accumulation of PR proteins, the hallmark of pathogen-induced SAR (Hoffland et al. 1995). In 1996, PGPR-ISR was for the first time demonstrated in the genetically accessible Arabidopsis model system, using WCS417 as the eliciting agent (Pieterse et al. 1996). WCS417-ISR was shown to be effective against F. oxysporum f. sp. raphani (Fig. 2f) and P. syringae pv. tomato in wild-type Arabidopsis Col-0 plants, but also in SA-degrading transgenic NahG plants. WCS417-ISR was also not associated with the activation of $P R$-genes, from which it was concluded that in contrast to pathogen-induced SAR, WCS417-ISR functions independently of SA and PR protein accumulation (Pieterse et al. 1996). In a follow up study, it was shown, that WCS417-ISR is regulated by the plant hormones jasmonic acid (JA) and ethylene (ET) (Fig. 3; Pieterse et al. 1998), and, thus, is regulated by a signaling pathway that is different from the one described for pathogen-induced SAR. Hence, to stress the clear difference from pathogen-induced SAR, the term "ISR" was hijacked for the phenomenon of beneficial rhizobacteria-mediated ISR, although it should be noted that the term ISR is officially an overarching term for all types of systemically induced resistance, including SAR (Hammerschmidt et al. 2001). Hence, it is advised to add information about the inducing agent in the term, e.g. PGPR-ISR, or WCS417-ISR when referring to ISR triggered by a specific microbial strain. Detailed protocols for carrying out Arabidopsis WCS417-ISR bioassays in a soil system and a high throughput system are described by Van Wees et al. (2013) and Cecchini et al. (2019), respectively.

After these first mechanistic discoveries on the molecular mechanism of PGPR-ISR in Arabidopsis, many studies followed. WCS417-ISR in Arabidopsis was demonstrated to be not only effective against $F$. oxysporum f. sp. raphani and $P$. syringae pv. tomato (Pieterse et al. 1996, 1998), but also against other fungal pathogens, such as Alternaria brassicicola (Ton et al. 2002c) and Botrytis cinerea (Maldonado-Gonzalez et al. 2015; Van der Ent et al. 2008); bacterial pathogens, such as Xanthomonas campestris pv. armoraciae (Ton et al. $2002 \mathrm{~b}, \mathrm{c})$; and the oomycete pathogen Hyaloperonospora arabidopsidis (Ton et al. 2002b, c; Van der Ent et al. 2008). However, WCS417-ISR was not effective against turnip crinkle virus (TCV) in Arabidopsis. The spectrum of effectiveness of WCS417-ISR overlaps only partly with that of pathogen-induced SAR (Ton et al. 2002c). Moreover, simultaneous activation of WCS417-ISR and SAmediated SAR resulted in an additive effect on the level of induced resistance (Van Wees et al. 2000), supporting the notion that both types of systemically induced resistance are based on different mechanisms. Nonetheless, both WCS417-ISR and SA-dependent SAR are both regulated via the transcriptional co-regulator NONEXPRESSOR OF PR-PROTEINS1 (NPR1) (Fig. 3; Pieterse et al. 1998; Van Wees et al. 2000), indicating that both induced defense signaling pathways share this central immune signaling component.

Earlier studies with WCS417 and other Pseudomonas spp. strains suggested that the genetics of plantmicrobe interactions are decisive in whether a specific PGPR can elicit ISR in a certain plant species. For instance, in radish, ISR could be elicited by WCS417 and Pseudomonas sp. strain WCS374, but not by Pseudomonas sp. strain WCS358 (Leeman et al. 1995b). In Arabidopsis, WCS417 and WCS358 were both capable of eliciting ISR, while WCS374 was not (Van Wees et al. 1997). Although, WCS417 is a versatile elicitor of ISR, it did not trigger ISR in tobacco (Van Loon et al. 2008). Genotype-dependency of WCS417-ISR was also demonstrated within different genotypes of a plant species. While Arabidopsis accessions Col-0 and Ler-0 were capable of mounting broad-spectrum WCS417ISR in the leaves, accessions RLD1 and Ws- 0 were not (Ton et al. 2001, 2002b; Van Wees et al. 1997). Genetic analysis of the difference between the WCS417-sensitive and -insensitive Arabidopsis accessions pointed to a reduced sensitivity to ET in RLD1 and Ws- 0 as the cause of their inability to express WCS417ISR (Ton et al. 2001). In other Arabidopsis mutant screens, the insensitivity to either ET or JA was repeatedly found to be related to the loss of WCS417-ISR (Knoester et al. 1999; Ton et al. 2002a), confirming the original findings that both hormones are required for WCS417-ISR (Pieterse et al. 1998). Although WCS417-ISR requires sensitivity to JA and ET, it is 
not accompanied by an increase in their production (Pieterse et al. 2000).

\section{Defense priming: Getting ready for battle}

While pathogen-induced SAR is clearly associated with abundant transcriptional changes in systemic tissues, including the activation of $P R$-genes, WCS417-ISR seemed to lack such hallmarks for its enhanced defensive state (Pieterse et al. 1998). Already in the first publication on WCS417-ISR in carnation, it was shown that WCS417 treated plants displayed an enhanced accumulation of antimicrobial phytoalexins at the site of pathogen attack, which became only apparent after pathogen infection (Van Peer et al. 1991). In Arabidopsis, similar cases of defense priming were observed, as WCS417-treated plants displayed an accelerated or enhanced expression of JA-responsive genes after infection by $P$. syringae pv. tomato or herbivory by $S$. exigua, which was associated with enhanced resistance against these attackers (Van Oosten et al. 2008; Van Wees et al. 1999). Additionally, WCS417 was shown to prime Arabidopsis plants to produce higher levels of ET upon infection by $P$. syringae pv. tomato (Hase et al. 2003), and to accelerate callose deposition upon infection by the downy mildew pathogen H. arabidopsidis (Van der Ent et al. 2008). These observations all pointed to the notion that colonization of the roots by WCS417 primes the whole plant body for accelerated basal defenses that are triggered in response to pathogen infection or insect attack (Fig. 3), which may explain the broad-spectrum effectiveness of this type of induced resistance.

To investigate the phenomenon of defense priming in more detail, Verhagen et al. (2004) performed a microarray study on Arabidopsis roots and leaves of WCS417-colonized plants. It was demonstrated that colonization of the roots results in massive transcriptional changes, but in the leaves no significant changes in gene expression could be detected. However, after challenge with $P$. syringae pv. tomato, WCS417colonized plants displayed an accelerated expression of a large set of defense-related genes. Many of the primed genes were dependent on JA and/or ET, which explains the dependency of WCS417-ISR for these hormones. Because no significant transcriptional changes could be observed in Arabidopsis leaves of WCS417colonized plants, Van der Ent et al. (2009) used a quantitative real-time PCR platform to analyze the expression pattern of a large set of transcription factor (TF) genes in the leaves, which are typically very lowly expressed and may have remained under the detection radar in the microarray study of Verhagen et al. (2004). Interestingly, Van der Ent and coworkers found several TF genes that are induced in leaves of WCS417colonized plants. Apparently, these TFs do not by themselves give rise to the downstream activation of defenserelated genes. It was postulated that this enhanced pool of latent TFs might facilitate the accelerated defense response that is typically observed in WCS417-ISRexpressing plants. Computational analysis of the promoters of the primed and non-primed genes of WCS417-stimulated plants by Pozo et al. (2008) revealed an enrichment for binding sites of the TF MYC2 (Fig. 3), and subsidiary biological experiments confirmed that this regulator of JA-dependent genes is required for WCS417-mediated defense priming.

\section{The root of WCS417-ISR}

Investigations on the molecular changes in the root in response to colonization by WCS417 initially yielded limited information. A screen of Arabidopsis enhancer trap and gene trap lines identified a $P R$-5-like gene that was specifically expressed in the vascular bundle of Arabidopsis roots in response to WCS417 colonization, but its function in the onset of ISR could not be established (Léon-Kloosterziel et al. 2005). However, the Arabidopsis microarray study of Verhagen et al. (2004) revealed approximately 100 genes that were significantly induced in Arabidopsis roots upon colonization by WCS417. By systematically testing T-DNA insertion mutants of the most highly induced genes, the root-specific TF MYB72 was identified as being essential for the onset of WCS417-ISR in the leaves (Van der Ent et al. 2008). Colonization of the roots by WCS417 induced the expression of the MYB72 gene locally in the roots (Figs. $2 \mathrm{~g}$ and 3). For the induction of MYB72, a physical interaction of WCS417 with the roots was not required, because VOCs produced by WCS417 were also capable of inducing MYB72 gene expression (Zamioudis et al. 2015). Blockage of photosynthesis in the leaves by keeping plants in the dark, or decapitation of the shoot immediately after treatment with WCS417 VOCs inhibited the WCS417 VOCs-induced expression of $M Y B 72$ in the roots, indicating that a signal from 
photosynthesizing leaves is required for the enhanced expression of MYB72 following WCS417 treatment (Zamioudis et al. 2015). Although the activation of MYB72 by WCS417 requires auxin signaling (Fig. 3; Stringlis et al. 2018a), mutations in the myb72 gene did not affect the plant growth-promoting effect of WCS417, indicating that the capacities to induce ISR and growth promotion are two independent traits of this strain (Zamioudis et al. 2013). MYB72 appeared also to be required for the onset of ISR triggered by the plant growth-promoting fungus Trichoderma asperellum (Segarra et al. 2009), suggesting that it functions as a node of convergence in induced resistance triggered by different beneficial microbes in the rhizosphere.

To identify WCS417-responsive genes regulated by transcription factor MYB72, Zamioudis et al. (2014) analyzed the transcriptome of WCS417-colonized wild-type, myb72 mutant, and MYB72-overexpressing Arabidopsis lines and discovered that the MYB72 gene regulatory module shows a significant overlap with the transcriptional response of roots to conditions of iron deficiency. MYB72 activation appeared to be dependent on the iron deficiency response regulator FIT1, and to be co-regulated with the iron deficiency response marker genes $F R O 2$ and $I R T 1$, both essential components of the plants iron uptake response (Fig. 3; Zamioudis et al. 2014, 2015). However, since WCS417 VOCs and WCS417 siderophore mutants were capable of triggering MYB72 gene expression, it could be ruled out that a physical iron deficiency, e.g. due to the secretion of iron chelating siderophores by WCS417, was the cause of the activation of the iron deficiency response genes by WCS417. Interestingly, VOCs produced by ISRinducing Trichoderma sp. strains were shown to similarly activate $M Y B 72$ and the iron deficiency marker genes (Martínez-Medina et al. 2017), indicating that different types of beneficial root-colonizing microbes engage the iron uptake response during the onset of ISR. Activation of the iron uptake response by WCS417, even under conditions of sufficient iron availability, results in enhanced iron nutrition for the plant, which contributes to the plant growth-promoting activity of WCS417 (Verbon et al. 2017, 2019).

Deeper analysis of the function of MYB72 revealed that it regulates genes that are important for the biosynthesis and secretion of iron-mobilizing coumarins, fluorescent phenolic compounds that are secreted into the rhizosphere under conditions of iron starvation, but also in response to colonization of the roots by WCS417
(Fig. 2h; Stringlis et al. 2018b; Zamioudis et al. 2014). One of the target genes of MYB72 is BGLU42 (Zamioudis et al. 2014). Mutant bglu42 plants are impaired in WCS417-ISR, while BGLU42-overexpressing plants show enhanced resistance against $B$. cinerea, $H$. arabidopsidis, and $P$. syringae pv. tomato (Trapet et al. 2020; Zamioudis et al. 2014), indicating that BGLU42 is an important component in WCS417-ISR (Fig. 3). BGLU42 encodes a $\beta$-glucosidase that catalyzes the deglycosylation of the coumarin scopolin, resulting in its bioactive aglycone scopoletin (Stringlis et al. 2018b). Interestingly, MYB72-dependent BGLU42 deglycosylation of scopolin mediates the secretion of scopoletin into the rhizosphere (Stringlis et al. 2018b; Zamioudis et al. 2014). Because overexpression of BGLU42 confers resistance against diverse plant pathogens, it is tempting to speculate that MYB72-dependent BGLU42 activity mobilizes a coumarin that then functions as a systemically transported ISR signal to prime systemic tissues for enhanced defense (Fig. 3; Stassen et al. 2020). However, this hypothesis remains to be tested.

\section{Among the stars: WCS417 in a root microbiome context}

Besides their function in the mobilization and uptake of iron from the soil environment, coumarins such as scopoletin, possess a selective antimicrobial activity (Stassen et al. 2020; Stringlis et al. 2019a). Using the mutant $f \sigma^{\prime} h 1$, which is impaired in the coumarin biosynthesis gene FERULOYL-COA 6'HYDROXYLASE1, it was shown that F6'H1-dependent coumarins have a significant effect on the composition of microbiota in the rhizosphere or in gnotobiotic conditions using microbial synthetic communities (Harbort et al. 2020; Stringlis et al. 2018b; Voges et al. 2019). Interestingly, WCS417 was shown to be highly tolerant to the antimicrobial activity of the coumarin scopoletin, while the soil-borne fungal pathogens $F$. oxysporum and Verticillium dahliae were strongly inhibited in their growth when exposed to scopoletin in the growth medium (Stringlis et al. 2018b). It was, thus, postulated that WCS417 joins forces with the plant to trigger MYB72/ BGLU42-dependent scopolin production and scopoletin secretion to improve its own niche establishment in the rhizosphere, resulting in WCS417-mediated plant growth and immunity benefits for the plant (Fig. 3; Stringlis et al. 2018b). Recently, it was shown that upon 
foliar infection with the oomycete pathogen $H$. arabidopsidis and the bacterial pathogen P. syringae pv. tomato, Arabidopsis plants are capable of recruiting ISR-inducing microbes to its root system (Berendsen et al. 2018; Yuan et al. 2018). Whether MYB72-dependent coumarins play a role in this selection process remains to be investigated.

To provide growth and health benefits to the plant, beneficial rhizobacteria in the root microbiome, such as WCS417, need to be accommodated by the host plant. The rhizosphere is a microbial hotspot with a huge diversity of microbes that all produce MAMPs that can be recognized by the plant's immune system (Hacquard et al. 2017). The 22-amino acid immunogenic epitope of WCS417's flagellin, flg22 ${ }^{417}$, was shown to trigger virtually the same massive MAMP-responsive gene expression pattern in Arabidopsis roots as its flg22 ${ }^{\mathrm{Pa}}$ counterpart of the pathogen Pseudomonas aeruginosa (Stringlis et al. 2018a). When applied to Arabidopsis seedlings, both flg $22^{\mathrm{Pa}}$ and flg $22^{417}$ strongly suppressed plant growth due to the growth-defense tradeoff typical for MTI responses (Fig. 2i; Gomez-Gomez et al. 1999; Pel and Pieterse 2013). However, live WCS417 cells promoted plant growth rather than suppressing it (Stringlis et al. 2018a), suggesting that WCS417 must prevent the activation of MTI responses, such as triggered by its flagellin epitope. In 2010, Millet et al. (2010) used the MAMP-responsive reporter line pCYP71A12::GUS, which develops GUS activity in the root tip in response to treatment with $\mathrm{flg} 22^{\mathrm{Pa}}$, to show that live WCS417 cells can actively suppress MTI responses (Fig. 2j). An RNA-seq based comparative analysis of the Arabidopsis root transcriptional response to live WCS417 cells and flg $22^{417}$ further demonstrated that live WCS417 cells strongly suppress the massive root transcriptional changes that are inflicted by its flagellin epitope (Stringlis et al. 2018a). The resulting suppression of local root immunity was hypothesized to be sufficient to prevent growth-defense tradeoffs and to facilitate WCS417 colonization and delivery of its beneficial services to the host plant.

The observation that live WCS417 cells can suppress local immune responses in the roots, showcases that this rhizobacterium possesses effective host immune evasion mechanisms. In $P$. aeruginosa and $P$. syringae pv. tomato it was demonstrated that their alkaline protease AprA, which is secreted in the extracellular space, is capable of degrading flagellin monomers while leaving the flagellum itself intact (Bardoel et al. 2011; Pel et al. 2014). P. aeruginosa and P. syringae pv. tomato mutants impaired in AprA were shown to be compromised in the evasion of immune recognition of their flagellin in their mammalian (human cell lines) and plant hosts (Arabidopsis and tomato). Interestingly, WCS417 also possesses an intact operon encoding AprA (Fig. 1). However, its role in host immune evasion remains to be elucidated.

Using the MAMP-responsive reporter line pCYP71A12::GUS (Fig. 2j; Millet et al. 2010), Yu et al. (2019a) demonstrated that over $40 \%$ of a collection of root microbiota that were isolated from the rhizosphere of Arabidopsis roots grown in a natural soil were, like WCS417, able to quench local root immune responses that were triggered by flg22. By performing a mutant screen with a Tn5 transposon library of Pseudomonas sp. WCS358, Yu et al. (2019a) identified two mutants that were incapable of suppressing flg22induced $p C Y P 71 A 12:: G U S$ MAMP-reporter gene expression. The mutants were impaired in the bacterial genes $p q q F$ and $c y o B$, which are required for the production of gluconic acid and its derivative 2-keto gluconic acid, and consequently lowered their extracellular $\mathrm{pH}$ to a lesser extent than the wild type strain. The acidification of the environment by gluconic acid was shown to be sufficient to suppress flg22-triggered immune responses in the roots. WCS417 produced even more gluconic acid and 2-ketogluconic acid than WCS358 in the in vitro growth medium, suggesting that also WCS417 can suppress local root immune responses via gluconic acid-mediated acidification of the root environment. Rhizosphere populations of the gluconic acid biosynthesis mutants were significantly reduced compared to wild type bacteria. This suggests that gluconic acid-mediated suppression of local root immune responses is an important function of the root microbiome, as it facilitates colonization of beneficial root microbiota (Yu et al. 2019a; Yu et al. 2019b). Arguably, acidification of the environment is likely not the only mechanism by which root microbiota can evade or suppress local host immune responses. Like pathogens, beneficial microbes have been shown to utilize host immune suppressive effectors to establish mutualistic relationships with their host plant (Zamioudis and Pieterse 2012). Whether the putative T3SS-secreted effectors of WCS417 (Fig. 1; Stringlis et al. 2019b) play a role in host immune evasion effectors in suppression of host immunity will need further investigation. 


\section{Concluding remarks}

The scientific journey that WCS417 has taken over time showcases how this model organism has been instrumental in uncovering biological concepts involved in the interaction between beneficial root-associated microbes and their host plants. From its original discovery as a potent biocontrol agent in wheat, to its central role in elucidating molecular mechanisms underlying rhizobacteria-ISR, plant growth promotion, and plantbeneficial microbe communication, WCS417 has delivered many exciting new insights in the plant-microbe interactions research field. As biology is complex by nature, it is important to note that the genetic potential of the genus Pseudomonas is highly diverse (Hesse et al. 2018; Stringlis et al. 2018c). Hence, the discoveries reported with WCS417 as a model are examples of how interactions between beneficial, free-living mutualists and their host plants can work in providing benefits to plant growth and health. They have provided a conceptual framework that provoked new questions and hypotheses. With the foresight of the rapid developments that unfold in the present era of next-generation sequencing-based root microbiome research, a detailed understanding of the biological concepts that shape binary plant-microbe and microbe-microbe interactions are more than ever essential to better understand the complex dynamic interactions that take place at the microbial community level. Many important questions at the microbiome level lie ahead of us: How do plants recruit beneficial, life-supporting microbiota to their root system that help them to cope with biotic and abiotic stress? Which plant traits and genes are key in maximizing profitable functions from the root microbiome? Which microbiome-encoded functions are recruited to the roots and how do they benefit the plant? How do beneficial root microbiota communicate with the plant immune system to maximize mutual profits? What makes a microbe rhizosphere competent and can this be improved? And most importantly, how can we harness knowledge from root microbiome processes to sustainably make our future crops more stress resilient and produce more with less input of agrochemicals? Over the past 30 years, WCS417 helped to lay a foundation for the developing field of plant-microbiome interactions, which holds great promise for the development of microbiome-optimized crops. However, in order to translate our scientific discoveries into more sustainable agricultural solutions with impact on global food security, the next generation of scientists faces exciting challenges for many years to come.

Acknowledgments This work was supported by Dutch Technology Foundation TTW, which is part of the Netherlands Organization of Scientific Research (NWO) and partly funded by the Ministry of Economic Affairs (Back2Roots Grant 14219) and NWO Gravity Programme MiCRop: Harnessing the second genome of plants (Grant 024.004.014). The invaluable intellectual input of past and present members of the Plant-Microbe Interactions research group at Utrecht University and many other colleagues in the field is greatly acknowledged.

Open Access This article is licensed under a Creative Commons Attribution 4.0 International License, which permits use, sharing, adaptation, distribution and reproduction in any medium or format, as long as you give appropriate credit to the original author(s) and the source, provide a link to the Creative Commons licence, and indicate if changes were made. The images or other third party material in this article are included in the article's Creative Commons licence, unless indicated otherwise in a credit line to the material. If material is not included in the article's Creative Commons licence and your intended use is not permitted by statutory regulation or exceeds the permitted use, you will need to obtain permission directly from the copyright holder. To view a copy of this licence, visit http://creativecommons.org/licenses/by/4.0/.

\section{References}

Alfano JR, Collmer A (2004) Type III secretion system effector proteins: double agents in bacterial disease and plant defense. Annu Rev Phytopathol 42:385-414

Alström S (1991) Induction of disease resistance in common bean susceptible to halo blight bacterial pathogen after seed bacterization with rhizosphere pseudomonads. J Gen Appl Microbiol 37:495-501

Bakker PAHM, Berendsen RL, Doornbos RF, Wintermans PCA, Pieterse CMJ (2013) The rhizospere revisited: root microbiomics. Front Plant Sci 4:165

Bakker PAHM, Pieterse CMJ, De Jonge R, Berendsen RL (2018) The soil-borne legacy. Cell 6:1178-1180

Bakker PAHM, Berendsen RL, Van Pelt JA, Vismans G, Yu K, Li E, Van Bentum S, Poppeliers SWM, Sanchez Gil JJ, Zhang $\mathrm{H}$, Goossens P, Stringlis IA, Song Y, de Jonge R, Pieterse CMJ (2020) The soil-borne identity and microbiome-assisted agriculture: looking back to the future. Mol Plant 13:13951402

Bardoel BW, Van der Ent S, Pel MJC, Tommassen J, Pieterse CMJ, Van Kessel KPM, Van Strijp JAG (2011) Pseudomonas evades immune recognition of flagellin in both mammals and plants. PLoS Pathog 7:e1002206

Berendsen RL, Van Verk MC, Stringlis IA, Zamioudis C, Tommassen J, Pieterse CMJ, Bakker PAHM (2015) Unearthing the genomes of plant-beneficial Pseudomonas model strains WCS358, WCS374 and WCS417. BMC Genomics 16:539 
Berendsen RL, Vismans G, Yu K, Song Y, Burgman W, Burmølle M, Herschend J, De Jonge R, Bakker PAHM, Pieterse CMJ (2018) Disease-induced assemblage of a plant-beneficial bacterial consortium. ISME J 12:1496-1507

Beskrovnaya P, Melnyk RA, Liu Z, Liu Y, Higgins MA, Song Y, Ryan KS, Haney CH (2020) Comparative genomics identified a genetic locus in plant-associated Pseudomonas spp. that is necessary for induced systemic susceptibility. mBio 11:e00575-e00520

Bigirimana J, Höfte M (2002) Induction of systemic resistance to Colletotrichum lindemuthianum in bean by a benzothiadiazole derivative and rhizobacteria. Phytoparasitica 30:159-168

Blin K, Shaw S, Steinke K, Villebro R, Ziemert N, Lee SY, Medema MH, Weber T (2019) antiSMASH 5.0: updates to the secondary metabolite genome mining pipeline. Nucleic Acids Res 47:W81-W87

Blom D, Fabbri C, Connor EC, Schiestl FP, Klauser DR, Boller T, Eberl L, Weisskopf L (2011) Production of plant growth modulating volatiles is widespread among rhizosphere bacteria and strongly depends on culture conditions. Environ Microbiol 13:3047-3058

Boonekamp PM, Pieterse CMJ, Govers F, Cornelissen BJC (2019) Johanna Westerdijk (1881-1961) - the impact of the grand lady of phytopathology in the Netherlands from 1917 to 2017. Eur J Plant Pathol 154:11-16

Canchignia H, Altimira F, Montes C, Sanchez E, Tapia E, Miccono M, Espinoza D, Aguirre C, Seeger M, Prieto H (2017) Candidate nematicidal proteins in a new Pseudomonas veronii isolate identified by its antagonistic properties against Xiphinema index. J Gen Appl Microbiol 63:11-21

Carrion VJ, Perez-Jaramillo J, Cordovez V, Tracanna V, De Hollander M, Ruiz-Buck D, Mendes LW, Van Ijcken WFJ, Gomez-Exposito R, Elsayed SS, Mohanraju P, Arifah A, Van der Oost J, Paulson JN, Mendes R, Van Wezel GP, Medema MH, Raaijmakers JM (2019) Pathogen-induced activation of disease-suppressive functions in the endophytic root microbiome. Science 366:606-612

Cecchini NM, Song Y, Roychoudhry S, Greenberg JT, Haney CH (2019) An improved bioassay to study Arabidopsis induced systemic resistance (ISR) against bacterial pathogens and insect pests. Bio-Protocol 9:e3236

Chiappero J, Cappellari LD, Alderete LGS, Palermo TB, Banchio E (2019) Plant growth promoting rhizobacteria improve the antioxidant status in Mentha piperita grown under drought stress leading to an enhancement of plant growth and total phenolic content. Ind Crops Pod 139:111553

Cole BJ, Feltcher ME, Waters RJ, Wetmore KM, Mucyn TS, Ryan EM, Wang G, Ul-Hasan S, McDonald M, Yoshikuni Y, Malmstrom RR, Deutschbauer AM, Dangl JL, Visel A (2017) Genome-wide identification of bacterial plant colonization genes. PLoS Biol 15:e2002860

Conrath U, Beckers GJM, Flors V, García-Agustín P, Jakab G, Mauch F, Newman M-A, Pieterse CMJ, Poinssot B, Pozo MJ, Pugin A, Schaffrath U, Ton J, Wendehenne W, Zimmerli L, Mauch-Mani B (2006) Priming: getting ready for battle. Mol Plant-Microbe Interact 19:1062-1071

Desrut A, Moumen B, Thibault F, Le Hir R, Coutos-Thévenot P, Vriet C (2020) Beneficial rhizobacteria Pseudomonas simiae WCS417 induces major transcriptional changes in plant sugar transport. J Exp Bot: eraa396, https://doi.org/10.1093 /jxb/eraa396

Duijff BJ, Meijer JW, Bakker PAHM, Schippers B (1993) Siderophore-mediated competition for iron and induced resistance in the suppression of fusarium wilt of carnation by fluorescent Pseudomonas spp. Neth J Plant Pathol 99:277289

Duijff BJ, Gianinazzi-Pearson V, Lemanceau P (1997) Involvement of the outer membrane lipopolysaccharides in the endophytic colonization of tomato roots by biocontrol Pseudomonas fluorescens strain WCS417r. New Phytol 135: 325-334

Duijff BJ, Pouhair D, Olivain C, Alabouvette C, Lemanceau P (1998) Implication of systemic induced resistance in the suppression of fusarium wilt of tomato by Pseudomonas fluorescens WCS417r and by nonpathogenic Fusarium oxysporum Fo47. Eur J Plant Pathol 104:903-910

Durrant WE, Dong X (2004) Systemic acquired resistance. Annu Rev Phytopathol 42:185-209

Fincheira P, Quiroz A (2018) Microbial volatiles as plant growth inducers. Micobiol Res 208:63-75

Gaffney T, Friedrich L, Vernooij B, Negrotto D, Nye G, Uknes S, Ward E, Kessmann H, Ryals J (1993) Requirement of salicylic acid for the induction of systemic acquired resistance. Science 261:754-756

Gao J, Sasse J, Lewald KM, Zhalnina K, Cornmesser LT, Duncombe TA, Yoshikuni Y, Vogel JP, Firestone MK, Northen TR (2018) Ecosystem fabrication (EcoFAB) protocols for the construction of laboratory ecosystems designed to study plant-microbe interactions. J Vis Exp 134: e57170

Gomez-Gomez L, Felix G, Boller T (1999) A single locus determines sensitivity to bacterial flagellin in Arabidopsis thaliana. Plant J 18:277-284

Grant JR, Stothard P (2008) The CGView server: a comparative genomics tool for circular genomes. Nucleic Acids Res 36: W181-W184

Hacquard S, Spaepen S, Garrido-Oter R, Schulze-Lefert P (2017) Interplay between innate immunity and the plant microbiota. Annu Rev Phytopathol 55:565-589

Hammerschmidt R, Métraux J-P, Van Loon LC (2001) Inducing resistance: a summary of papers presented at the first international symposium on induced resistance to plant diseases, Corfu, may 2000. Eur J Plant Pathol 107:1-6

Haney CH, Samuel BS, Bush J, Ausubel FM (2015) Associations with rhizosphere bacteria can confer an adaptive advantage to plants. Nat Plants 1:1-9

Haney CH, Wiesmann CL, Shapiro LR, Melnyk RA, O'Sullivan LR, Khorasani S, Xiao L, Han JT, Bush J, Carrillo J, Pierce NE, Ausubel FM (2018) Rhizosphere-associated Pseudomonas induce systemic resistance to herbivores at the cost of susceptibility to bacterial pathogens. Mol Ecol 27:1833-1847

Harbort CJ, Hashimoto M, Inoue H, Niu Y, Guan R, Rombola AD, Kopriva S, Voges MJEEE, Sattely ES, Garrido-Oter R, Schulze-Lefert P (2020) Root-secreted coumarins and microbiota interact to improve iron nutrition in Arabidopsis. Cell Host Microbe. https://doi.org/10.1016/j.chom.2020.09.006

Hartmann A, Schmid M, Van Tuinen D, Berg G (2009) Plantdriven selection of microbes. Plant Soil 321:235-257

Hase S, Van Pelt JA, Van Loon LC, Pieterse CMJ (2003) Colonization of Arabidopsis roots by Pseudomonas 
fluorescens primes the plant to produce higher levels of ethylene upon pathogen infection. Physiol Mol Plant Pathol 62:219-226

Hesse C, Schulz F, Bull CT, Shaffer BT, Yan Q, Shapiro N, Hassan KA, Varghese N, Elbourne LDH, Paulsen IT, Kyrpides N, Woyke T, Loper JE (2018) Genome-based evolutionary history of Pseudomonas spp. Environ Microbiol 20:2142-2159

Hiltner L (1904) Uberneuere erfahrungen und probleme auf dem gebieteder bodenbakteriologie unter besonderden berucksichtigung und Brache. Arb Dtsch Landwirtsch Gesellschaft 98:59-78

Hoffland E, Pieterse CMJ, Bik L, Van Pelt JA (1995) Induced systemic resistance in radish is not associated with accumulation of pathogenesis-related proteins. Physiol Mol Plant Pathol 46:309-320

Kazan K, Manners JM (2009) Linking development to defense: auxin in plant-pathogen interactions. Trends Plant Sci 14: 373-382

Kloepper JW, Leong J, Teintze M, Schroth MN (1980) Enhanced plant growth by siderophores produced by plant growthpromoting rhizobacteria. Nature 286:885-886

Knoester M, Pieterse CMJ, Bol JF, Van Loon LC (1999) Systemic resistance in Arabidopsis induced by rhizobacteria requires ethylene-dependent signaling at the site of application. Mol Plant-Microbe Interact 12:720-727

Lamers JG, Schippers B, Geels FP (1988) Soil-borne diseases of wheat in the Netherlands and results of seed bacterization with pseudomonads against Gaeumannomyces graminis var. tritici, associated with disease resistance. In: Jorna ML, Slootmaker LAJ (eds) Cereal breeding related to integrated cereal production. Pudoc, Wageningen

Leeman M, Van Pelt JA, Den Ouden FM, Heinsbroek M, Bakker PAHM, Schippers B (1995a) Induction of systemic resistance against fusarium wilt of radish by lipopolysaccharides of Pseudomonas fluorescens. Phytopathology 85:1021-1027

Leeman M, Van Pelt JA, Den Ouden FM, Heinsbroek M, Bakker PAHM, Schippers B (1995b) Induction of systemic resistance by Pseudomonas fluorescens in radish cultivars differing in susceptibility to fusarium wilt, using a novel bioassay. Eur J Plant Pathol 101:655-664

Leeman M, Den Ouden FM, Van Pelt JA, Cornelissen C, Matamala-Garros A, Bakker PAHM, Schippers B (1996a) Suppression of fusarium wilt of radish by co-inoculation of fluorescent Pseudomonas spp. and root-colonizing fungi. Eur J Plant Pathol 102:21-31

Leeman M, Den Ouden FM, Van Pelt JA, Dirkx FPM, Steijl H, Bakker PAHM, Schippers B (1996b) Iron availability affects induction of systemic resistance to fusarium wilt of radish by Pseudomonas fluorescens. Phytopathology 86:149-155

Léon-Kloosterziel KM, Verhagen BWM, Keurentjes JJB, Van Pelt JA, Rep M, Van Loon LC, Pieterse CMJ (2005) Colonization of the Arabidopsis rhizosphere by fluorescent Pseudomonas spp. activates a root-specific, ethyleneresponsive $P R-5$ gene in the vascular bundle. Plant Mol Biol 57:731-748

Loo EP, Tajima Y, Yamada K, Hirase T, Ariga H, Fujiwara T, Tanaka K, Taji T, Somssich IE, Parker JE, Saijo Y (2020) Pattern recognition receptors confer plant salt tolerance via WRKY18/WRKY40 transcription factors. bioRxiv: https://doi.org/10.1101/2020.05.07.082172
Loper JE, Hassan KA, Mavrodi DV, Davis EW, Lim CK, Shaffer BT, LDH E, Stockwell VO, Hartney SL, Breakwell K, Henkels MD, Tetu SG, Rangel LI, Kidarsa TA, Wilson NL, JEV DM, Song CX, Blumhagen R, Radune D, Hostetler JB, Brinkac LM, Durkin AS, Kluepfel DA, Wechter WP, Anderson AJ, Kim YC, Pierson LS, Pierson EA, Lindow SE, Kobayashi DY, Raaijmakers JM, Weller DM, Thomashow LS, Allen AE, Paulsen IT (2012) Comparative genomics of plant-associated Pseudomonas spp.: Insights into diversity and inheritance of traits involved in multitrophic interactions. PLoS Genet 8:e1002784

Lugtenberg B, Kamilova F (2009) Plant-growth-promoting rhizobacteria. Annu Rev Microbiol 63:541-556

Lugtenberg BJJ, Dekkers L, Bloemberg GV (2001) Molecular determinants of rhizosphere colonization by Pseudomonas. Annu Rev Phytopathol 39:461-490

Maldonado-Gonzalez MM, Bakker P, Prieto P, Mercado-Blanco J (2015) Arabidopsis thaliana as a tool to identify traits involved in Verticillium dahliae biocontrol by the olive root endophyte Pseudomonas fluorescens PICF7. Front Microbiol 6:266

Martínez-García PM, Ruano-Rosa D, Schilirò E, Prieto P, Ramos C, Rodríguez-Palenzuela P, Mercado-Blanco J (2015) Complete genome sequence of Pseudomonas fluorescens strain PICF7, an indigenous root endophyte from olive (Olea europaea L.) and effective biocontrol agent against Verticillium dahliae. Stand Genomic Sci 10:10

Martinez-Medina A, Flors V, Heil M, Mauch-Mani B, Pieterse CMJ, Pozo MJ, Ton J, Van Dam NM, Conrath U (2016) Recognizing plant defense priming. Trends Plant Sci 21: 818-822

Martínez-Medina A, Van Wees SCM, Pieterse CMJ (2017) Airborne signals by Trichoderma fungi stimulate iron uptake responses in roots resulting in priming of jasmonic aciddependent defences in shoots of Arabidopsis thaliana and Solanum lycopersicum. Plant Cell Environ 40:2691-2705

Mathimaran N, Srivastava R, Wiemken A, Sharma AK, Boller T (2012) Genome sequences of two plant growth-promoting fluorescent Pseudomonas strains, R62 and R81. J Bacteriol 194:3272-3273

Meziane H, Van der Sluis I, Van Loon LC, Höfte M, Bakker PAHM (2005) Determinants of Pseudomonas putida WCS358 involved in inducing systemic resistance in plants. Mol Plant Pathol 6:177-185

Millet YA, Danna CH, Clay NK, Songnuan W, Simon MD, Werck-Reichhart D, Ausubel FM (2010) Innate immune responses activated in Arabidopsis roots by microbeassociated molecular patterns. Plant Cell 22:973-990

Mulet M, Lalucat J, García-Valdés E (2010) DNA sequence-based analysis of the Pseudomonas species. Environ Microbiol 12: $1513-1530$

Nel B, Steinberg C, Labuschagne N, Viljoen A (2006) The potential of nonpathogenic Fusarium oxysporum and other biological control organisms for suppressing fusarium wilt of banana. Plant Pathol 55:217-223

Pangesti N, Reichelt M, Van de Mortel JE, Kapsomenou E, Gershenzon J, Van Loon JJA, Dicke M, Pineda A (2016) Jasmonic acid and ethylene signaling pathways regulate glucosinolate levels in plants during rhizobacteria-induced systemic resistance against a leaf-chewing herbivore. J Chem Ecol 42:1212-1225 
Pangesti N, Vandenbrande S, Pineda A, Dicke M, Raaijmakers JM, Van Loon JJA (2017) Antagonism between two rootassociated beneficial Pseudomonas strains does not affect plant growth promotion and induced resistance against a leaf-chewing herbivore. FEMS Microbiol Ecol 93:fix038

Pel MJC, Pieterse CMJ (2013) Microbial recognition and evasion of host immunity. J Exp Bot 64:1237-1248

Pel MJC, Van Dijken AJH, Bardoel BW, Seidl MF, Van der Ent S, Van Strijp JAG, Pieterse CMJ (2014) Pseudomonas syringae evades host immunity by degrading flagellin monomers with alkaline protease AprA. Mol Plant-Microbe Interact 27:603610

Pieterse CMJ, Van Loon LC (1999) Salicylic acid-independent plant defence pathways. Trends Plant Sci 4:52-58

Pieterse CMJ, Van Wees SCM, Hoffland E, Van Pelt JA, Van Loon LC (1996) Systemic resistance in Arabidopsis induced by biocontrol bacteria is independent of salicylic acid accumulation and pathogenesis-related gene expression. Plant Cell 8:1225-1237

Pieterse CMJ, Van Wees SCM, Van Pelt JA, Knoester M, Laan R, Gerrits H, Weisbeek PJ, Van Loon LC (1998) A novel signaling pathway controlling induced systemic resistance in Arabidopsis. Plant Cell 10:1571-1580

Pieterse CMJ, Van Pelt JA, Ton J, Parchmann S, Mueller MJ, Buchala AJ, Métraux J-P, Van Loon LC (2000) Rhizobacteria-mediated induced systemic resistance (ISR) in Arabidopsis requires sensitivity to jasmonate and ethylene but is not accompanied by an increase in their production. Physiol Mol Plant Pathol 57:123-134

Pieterse CMJ, Zamioudis C, Berendsen RL, Weller DM, Van Wees SCM, Bakker PAHM (2014) Induced systemic resistance by beneficial microbes. Annu Rev Phytopathol 52: 347-375

Pieterse CMJ, De Jonge R, Berendsen RL (2016) The soil-borne supremacy. Trends Plant Sci 21:171-173

Pineda A, Zheng S-J, Van Loon JJA, Pieterse CMJ, Dicke M (2010) Helping plants to deal with insects: the role of beneficial soil-borne microbes. Trends Plant Sci 15:507-514

Pineda A, Zheng SJ, Van Loon JJA, Dicke M (2012) Rhizobacteria modify plant-aphid interactions: a case of induced systemic susceptibility. Plant Biol 14:83-90

Poitout A, Martiniere A, Kucharczyk B, Queruel N, Silva-Andia J, Mashkoor S, Gamet L, Varoquaux F, Paris N, Sentenac H, Touraine B, Desbrosses G (2017) Local signalling pathways regulate the Arabidopsis root developmental response to Mesorhizobium loti inoculation. J Exp Bot 68:1199-1211

Pozo MJ, Van der Ent S, Van Loon LC, Pieterse CMJ (2008) Transcription factor MYC2 is involved in priming for enhanced defense during rhizobacteria-induced systemic resistance in Arabidopsis thaliana. New Phytol 180:511-523

Preston GM, Bertrand N, Rainey PB (2001) Type III secretion in plant growth-promoting Pseudomonas fluorescens SBW25. Mol Microbiol 41:999-1014

Ran LX, Liu CY, Wu GJ, Van Loon LC, Bakker PAHM (2005) Suppression of bacterial wilt in Eucalyptus urophylla by fluorescent Pseudomonas spp. in China. Biol Control 32: 111-120

Regaiolo A, Dominelli N, Andresen K, Heermann R (2020) The biocontrol agent and insect pathogen Photorhabdus luminescens interacts with plant roots. Appl Environ Microbiol 86:e00891-e00820
Roesti D, Gaur R, Johri BN, Imfeld G, Sharma S, Kawaljeet K, Aragno M (2006) Plant growth stage, fertiliser management and bio-inoculation of arbuscular mycorrhizal fungi and plant growth promoting rhizobacteria affect the rhizobacterial community structure in rain-fed wheat fields. Soil Biol Biochem 38:1111-1120

Ross AF (1961) Systemic acquired resistance induced by localized virus infections in plants. Virology 14:340-358

Schippers B, Roosje GS (1997) Hundred years of history and the future of the foundation 'Willie Commelin Scholten Phytopathological Laboratory'. Eur J Plant Pathol 103:667671

Schippers B, Bakker AW, Bakker PAHM (1987) Interactions of deleterious and beneficial rhizosphere microorganisms and the effect of cropping practices. Annu Rev Phytopathol 25: $339-358$

Schwachtje J, Karojet S, Kunz S, Brouwer S, Van Dongen JT (2012) Plant-growth promoting effect of newly isolated rhizobacteria varies between two Arabidopsis ecotypes. Plant Signal Behav 7:623-627

Segarra G, Van der Ent S, Trillas I, Pieterse CMJ (2009) MYB72, a node of convergence in induced systemic resistance triggered by a fungal and a bacterial beneficial microbe. Plant Biol 11:90-96

Spaepen S, Vanderleyden J (2011) Auxin and plant-microbe interactions. Cold Spring Harb Perspect Biol 3:a001438

Stassen MJJ, Hsu S-H, Pieterse CMJ, Stringlis IA (2020) Coumarin communication along the microbiome-root-shoot axis. Trends Plant Sci. https://doi.org/10.1016/j. tplants.2020.09.008

Stringlis I, Proietti S, Hickman R, Van Verk MC, Zamioudis C, Pieterse CMJ (2018a) Root transcriptional dynamics induced by beneficial rhizobacteria and microbial immune elicitors reveal signatures of adaptation to mutualists. Plant J 93:166180

Stringlis IA, Yu K, Feussner K, De Jonge R, Van Bentum S, Van Verk MC, Berendsen RL, Bakker PAHM, Feussner I, Pieterse CMJ (2018b) MYB72-dependent coumarin exudation shapes root microbiome assembly to promote plant health. Proc Natl Acad Sci U S A 115:5213-5222

Stringlis IA, Zhang H, Pieterse CMJ, Bolton MD, De Jonge R (2018c) Microbial small molecules - weapons of plant subversion. Nat Prod Rep 35:410-433

Stringlis IA, De Jonge R, Pieterse CMJ (2019a) The age of coumarins in plant-microbe interactions. Plant Cell Physiol 60:1405-1419

Stringlis IA, Zamioudis C, Berendsen RL, Bakker PAHM, Pieterse CMJ (2019b) Type III secretion system of beneficial rhizobacteria Pseudomonas simiae WCS417 and Pseudomonas defensor WCS374. Front Microbiol 10:1631

Ton J, Davison S, Van Wees SCM, Van Loon LC, Pieterse CMJ (2001) The Arabidopsis ISRI locus controlling rhizobacteriamediated induced systemic resistance is involved in ethylene signaling. Plant Physiol 125:652-661

Ton J, De Vos M, Robben C, Buchala A, Métraux J-P, Van Loon LC, Pieterse CMJ (2002a) Characterization of Arabidopsis enhanced disease susceptibility mutants that are affected in systemically induced resistance. Plant J 29:11-21

Ton J, Van Pelt JA, Van Loon LC, Pieterse CMJ (2002b) The Arabidopsis ISRI locus is required for rhizobacteria- 
mediated induced systemic resistance against different pathogens. Plant Biol 4:224-227

Ton J, Van Pelt JA, Van Loon LC, Pieterse CMJ (2002c) Differential effectiveness of salicylate-dependent and jasmonate/ethylene-dependent induced resistance in Arabidopsis. Mol Plant-Microbe Interact 15:27-34

Trapet PL, Verbon EH, Bosma RR, Voordendag K, Van Pelt JA, Pieterse CMJ (2020) Unearthing mechanisms underlying iron deficiency-induced resistance against pathogens with different lifestyles. J Exp Bot. https://doi.org/10.1093 /jxb/eraa535

Van der Ent S, Verhagen BWM, Van Doorn R, Bakker D, Verlaan MG, Pel MJC, Joosten RG, Proveniers MCG, Van Loon LC, Ton J, Pieterse CMJ (2008) MYB72 is required in early signaling steps of rhizobacteria-induced systemic resistance in Arabidopsis. Plant Physiol 146:1293-1304

Van der Ent S, Van Hulten MHA, Pozo MJ, Czechowski T, Udvardi MK, Pieterse CMJ, Ton J (2009) Priming of plant innate immunity by rhizobacteria and $\beta$-aminobutyric acid: differences and similarities in regulation. New Phytol 183: 419-431

Van Loon LC, Van Kammen A (1970) Polyacrylamide disc electrophoresis of the soluble leaf proteins from Nicotiana tabacum var. "Samsun" and "Samsun NN". II. Changes in protein constitution after infection with tobacco mosaic virus. Virology 40:190-211

Van Loon LC, Rep M, Pieterse CMJ (2006) Significance of inducible defense-related proteins in infected plants. Annu Rev Phytopathol 44:135-162

Van Loon LC, Bakker PAHM, Van der Heijdt WHW, Wendehenne D, Pugin A (2008) Early responses of tobacco suspension cells to rhizobacterial elicitors of induced systemic resistance. Mol Plant-Microbe Interact 21:1609-1621

Van Oosten VR, Bodenhausen N, Reymond P, Van Pelt JA, Van Loon LC, Dicke M, Pieterse CMJ (2008) Differential effectiveness of microbially induced resistance against herbivorous insects in Arabidopsis. Mol Plant-Microbe Interact 21: 919-930

Van Peer R, Schippers B (1992) Lipopolysaccharides of plantgrowth promoting Pseudomonas sp. strain WCS417r induce resistance in carnation to fusarium wilt. Neth J Plant Pathol 98:129-139

Van Peer R, Van Kuik AJ, Rattink H, Schippers B (1990) Control of Fusarium wilt in carnation grown on rockwool by Pseudomonas sp. strain WCS417r and by Fe-EDDHA. Neth J Plant Pathol 96:119-132

Van Peer R, Niemann GJ, Schippers B (1991) Induced resistance and phytoalexin accumulation in biological control of fusarium wilt of carnation by Pseudomonas sp. strain WCS417r. Phytopathology 81:728-734

Van Wees SCM, Pieterse CMJ, Trijssenaar A, Van't Westende YAM, Hartog F, Van Loon LC (1997) Differential induction of systemic resistance in Arabidopsis by biocontrol bacteria. Mol Plant-Microbe Interact 10:716-724

Van Wees SCM, Luijendijk M, Smoorenburg I, Van Loon LC, Pieterse CMJ (1999) Rhizobacteria-mediated induced systemic resistance (ISR) in Arabidopsis is not associated with a direct effect on expression of known defense-related genes but stimulates the expression of the jasmonate-inducible gene Atvsp upon challenge. Plant Mol Biol 41:537-549
Van Wees SCM, De Swart EAM, Van Pelt JA, Van Loon LC, Pieterse CMJ (2000) Enhancement of induced disease resistance by simultaneous activation of salicylate- and jasmonate-dependent defense pathways in Arabidopsis thaliana. Proc Natl Acad Sci U S A 97:8711-8716

Van Wees SCM, Van Pelt JA, Bakker PAHM, Pieterse CMJ (2013) Bioassays for assessing jasmonate-dependent defenses triggered by pathogens, herbivorous insects, or beneficial rhizobacteria. Methods Mol Biol 1011:35-49

Vela AI, Gutierrez MC, Falsen E, Rollan E, Simarro I, Garcia P, Dominguez L, Ventosa A, Fernandez-Garayzabal JF (2006) Pseudomonas simiae sp nov., isolated from clinical specimens from monkeys (Callithrix geoffroyi). Int J Syst Evol Microbiol 56:2671-2676

Verbon EH, Liberman LM (2016) Beneficial microbes affect endogenous mechanisms controlling root development. Trends Plant Sci 21:218-229

Verbon EH, Trapet PL, Stringlis IA, Kruijs S, Bakker PAHM, Pieterse CMJ (2017) Iron and immunity. Annu Rev Phytopathol 55:355-375

Verbon EH, Trapet PL, Kruijs S, Temple-Boyer-Dury C, Rouwenhorst TG, Pieterse CMJ (2019) Rhizobacteriamediated activation of the Fe deficiency response in Arabidopsis roots: impact on Fe status and signaling. Front Plant Sci 10:909

Verhagen BWM, Glazebrook J, Zhu T, Chang H-S, Van Loon LC, Pieterse CMJ (2004) The transcriptome of rhizobacteriainduced systemic resistance in Arabidopsis. Mol PlantMicrobe Interact 17:895-908

Verhagen BWM, Trotel-Aziz P, Couderchet M, Hofte M, Aziz A (2010) Pseudomonas spp.-induced systemic resistance to Botrytis cinerea is associated with induction and priming of defence responses in grapevine. J Exp Bot 61:249-260

Vlot AC, Dempsey DA, Klessig DF (2009) Salicylic acid, a multifaceted hormone to combat disease. Annu Rev Phytopathol 47:177-206

Voges MJEEE, Bai Y, Schulze-Lefert P, Sattely ES (2019) Plantderived coumarins shape the composition of an Arabidopsis synthetic root microbiome. Proc Natl Acad Sci U S A 116: 12558-12565

Wei G, Kloepper JW, Tuzun S (1991) Induction of systemic resistance of cucumber to Colletrotichum orbiculare by select strains of plant-growth promoting rhizobacteria. Phytopathology 81:1508-1512

Weller DM (1988) Biological control of soilborne plant pathogens in the rhizosphere with bacteria. Annu Rev Phytopathol 26: 379-407

Williams A, Petriacq P, Beetling DJ, Cotton TEA, Ton J (2018) Impacts of atmospheric $\mathrm{CO}_{2}$ and soil nutritional value on plant responses to rhizosphere colonization by soil bacteria. Front Plant Sci 9:1493

Wintermans PCA, Bakker PAHM, Pieterse CMJ (2016) Natural genetic variation in Arabidopsis for responsiveness to plant growth-promoting rhizobacteria. Plant Mol Biol 90:623-634

Yu K, Liu Y, Tichelaar R, Savant N, Lagendijk E, Van Kuijk SJL, Stringlis IA, Van Dijken AJH, Pieterse CMJ, Bakker PAHM, Haney CH, Berendsen RL (2019a) Rhizosphere-associated Pseudomonas suppress local root immune responses by gluconic acid-mediated lowering of environmental $\mathrm{pH}$. Curr Biol 29:3913-3920 
Yu K, Pieterse CMJ, Bakker PAHM, Berendsen RL (2019b) Beneficial microbes going underground of root immunity. Plant Cell Environ 42:2860-2870

Yuan J, Zhao J, Wen T, Zhao M, Li R, Goossens P, Huang Q, Bai Y, Vivanco JM, Kowalchuk GA, Berendsen RL, Shen Q (2018) Root exudates drive the soil-borne legacy of aboveground pathogen infection. Microbiome 6:156

Yue JP, Hu XY, Huang JL (2014) Origin of plant auxin biosynthesis. Trends Plant Sci 19:764-770

Zamioudis C, Pieterse CMJ (2012) Modulation of host immunity by beneficial microbes. Mol Plant-Microbe Interact 25:139150

Zamioudis C, Mastranesti P, Dhonukshe P, Blilou I, Pieterse CMJ (2013) Unraveling root developmental programs initiated by beneficial Pseudomonas spp. bacteria. Plant Physiol 162: 304-318
Zamioudis C, Hanson J, Pieterse CMJ (2014) $\beta$-Glucosidase BGLU42 is a MYB72-dependent key regulator of rhizobacteria-induced systemic resistance and modulates iron deficiency responses in Arabidopsis roots. New Phytol 204: 368-379

Zamioudis C, Korteland J, Van Pelt JA, Van Hamersveld M, Dombrowski N, Bai Y, Hanson J, Van Verk MC, Ling HQ, Schulze-Lefert P, Pieterse CMJ (2015) Rhizobacterial volatiles and photosynthesis-related signals coordinate MYB72 expression in Arabidopsis roots during onset of induced systemic resistance and iron-deficiency responses. Plant J $84: 309-322$

Publisher's note Springer Nature remains neutral with regard to jurisdictional claims in published maps and institutional affiliations. 